\title{
Effect of Methyl Jasmonate on Vegetative Growth and Formation of Potato Tuber (Solanum tuberosum L. var. Granola)
}

\author{
TRIANA ROHMAWATI ${ }^{1}$, KUMALA DEWI $^{1}$ \\ ${ }^{1}$ Laboratory of Plant Physiology, Faculty of Biology, Universitas Gadjah Mada \\ Jl. Teknika Selatan, Sekip Utara, Yogyakarta, Indonesia. 55281 \\ *Email: triana.rohmawati@mail.ugm.ac.id \\ Received 19 June 2018; Received in revised form 16 July 2018; \\ Accepted 27 June 2019; Available online 30 June 2019
}

\begin{abstract}
Potato (Solanum tuberosum L.) is one of the main commodities of food crops in Indonesia that are rich in vitamins, antioxidants, and carbohydrates. One of the most popular varieties of vegetable potatoes and become the leading varieties of producer farmers is Granola. Methyl jasmonate is a hormone known to modulate physiological events in plants such as encouraging tuber formation, functioning in vegetative development and fruit development. This study aims to evaluate the influence of methyl jasmonate on vegetative growth and potato tuber formation. In the fourth weeks, the methyl jasmonate applied with concentrations: 0 ppm (control), 12.5 ppm, 25 ppm, 50 ppm, 75 ppm, and 100 ppm. Measurement of plant height, number of leaves performed at the age of 4 weeks until the age of 7 weeks. The leaf area measured in seven weeks. The height of the plant measured in 4 weeks until 7 weeks. The leaf area measured in 7 weeks. Once the harvest performed, then measure the amount and weight of the tuber. Data were analyzed using ANOVA One way, if the data represent a significant difference, then continued with DMRT with an error rate of 5\%. The results showed that methyl jasmonate administration generally had no effect on vegetative growth (plant height, leaf number, and leaf area) of the potato plant. The methyl jasmonate application tends to decrease the number of tubers formed but increases the size and weight of the tubers.
\end{abstract}

Keywords: methyl jasmonate; potato; tuber formation; vegetative growth

\section{INTRODUCTION}

Potatoes (Solanum tuberosum L.) are one of the C3 plant species and a member of the Solanaceae family. Botanically, potatoes represent an annual and herbaceous plant. Potatoes could become the main food commodities in Indonesia besides rice, wheat, and corn. Potatoes have increased along with the population growth. Potatoes carry out several substantial roles as crops. One of them is potatoes as a vegetable with excellent economic value in the world and great potential as nutritious foods. Potatoes contain protein, fat, iron, potassium, phosphorus, vitamin $\mathrm{B}$, vitamin $\mathrm{C}$, and some vitamin A those are good for the body. Many of the compounds of potatoes contribute as the antioxidants (Camire et al., 2009).

Granola variety is the excellent potatoes and the easiest marketed for Indonesian farmers hence it has been until now recognized. Granola variety is one of the very popular as a vegetable, and still being superior variety among the farmers. Granola variety is dominating potatoes production, with a setting area reaching $80-90 \%$ of the crop. This variety is the best choice of the farmers because it is excellent yields, short life cycles, and wide adaptability. The potatoes productions affected by ideal location and adequate care. It also influenced by the varieties of potatoes grown because every potatoes variety produces different potential results (BPTP SUMSEL, 2014). This variety is relatively susceptible to rotten leaves (Fusarium spp.) and bacterial wilt (Fusarium oxysporum), but it is quite resistant to viruses. Granola's resistance to PLRV (Potatoes Leaf Roll Virus) and PVY (Potatoes Virus Y) contributed to making it successful in Indonesia (De Putter et al., 2014). In Indonesia, potatoes (Solanum tuberosum L.) are strategic plants as the supply food to support food security. On demands for potatoes, it did not balance with good tuber productivity. Poor tuber, damage caused by plant pests, and unacceptable uses of seeds can affect the crop yields.

The methyl jasmonate knows to modulate physiological events in higher plants, like plant 
defense responses to biotic and abiotic stresses, inducing a flowering, and aging. This compound also reported ruling the regulation of morphogenesis plant organ (Wei-Min et al., 2003). The methyl jasmonate also reported providing a substantial role as a molecule that provides plant defense signals from planteating insects and neurotropic pathogens (Schaller \& Stinzi, 2008). Methyl jasmonate can also trigger the formation of potato tubers. Massive amounts of methyl jasmonate can encourage the accumulation of protein storage. The response of methyl jasmonate and tuberonic acid (one of the methyl jasmonate derivatives) are thought to play a role in the formation of tuber formation.

\section{MATERIALS AND METHODS}

This research was conducted in Kledung Regional, Temanggung, Central Java. The elevation of crops is \pm 1.138 masl with a maximum temperature of $29^{\circ} \mathrm{C}$ and the minimum temperature of $18^{\circ} \mathrm{C}$. The humidity is about 25-50\%. Potato seeds of Granola variety (G4) that used in this research are 36 potatoes with $1-2 \mathrm{~cm}$ buds that planted in the mound-planting hole. In the fourth weeks, the methyl jasmonate applied with concentrations: 0 ppm (control), 12.5 ppm, 25 ppm, 50 ppm, 75 ppm, and $100 \mathrm{ppm}$. The height of the plant measured in 4 weeks until 7 weeks. The leaf area measured in 7 weeks. Treatment of potato plants done by fertilized, watered and suppressed the pests every week. The potatoes harvested in 110 days. Once the harvest performed, then measure the amount and weight of the tuber. Data were analyzed using ANOVA One way, if the data represent a significant difference, then continued with DMRT with an error rate of $5 \%$.

\section{RESULT AND DISCUSSION}

In observing the effect of methyl jasmonate on vegetative growth and the formation of potatoes tubers (Solanum tuberosum L. var. Granola) the following results obtained:

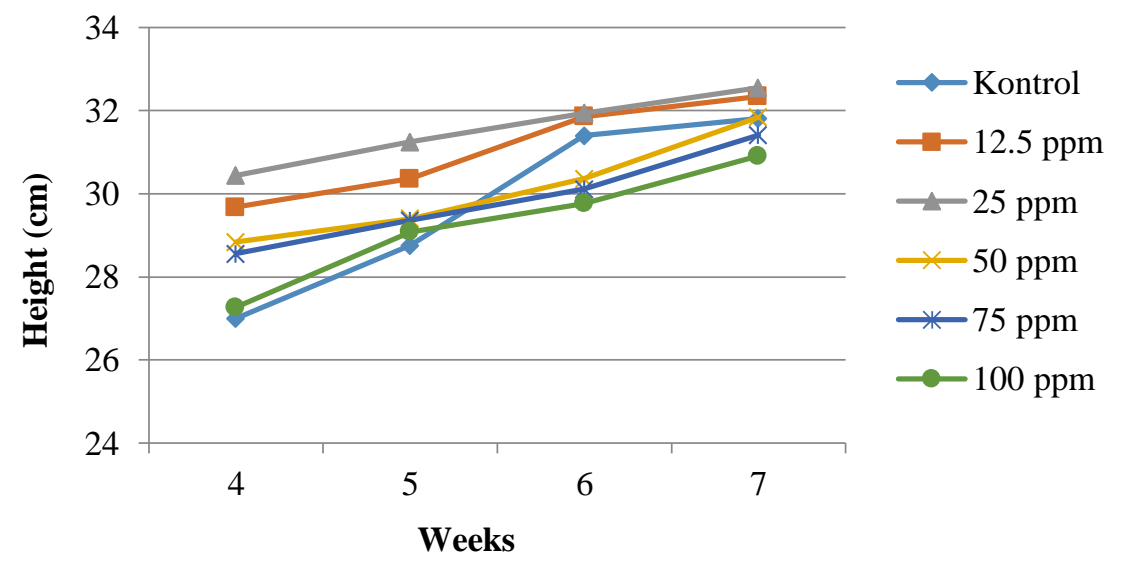

Figure 1. The effect of methyl jasmonate on potato plant height (Solanum tuberosum L. var. Granola)

Aside from being an elicitor, methyl jasmonate known to affect the growth and development process of plants. It can inhibit cell metabolism in significant concentrations while at deep concentrations, it can increase cell division. In Figure 1 shown that the administration of methyl jasmonate tends not to affect plant height. The hormone treatment was given once at the $4^{\text {th }}$ week. This shows that the one-time administration of methyl jasmonate has not been effective in influencing the growth of potato height (Solanum tuberosum L. var. Granola). The application of methyl jasmonate can inhibit plant growth due to the metabolic activity of jasmonic acid associated with the disruption of biosynthesis and bioactivity of the hormone endogenous gibberellins in plant growth process. Gibberellin hormones in plants can interact synergistically or antigenically with methyl jasmonate and the reduced gibberellin hormone has the potential to inhibit growth (Pang et al., 2006; Kazan et al., 2012). 
Table 1. Effect of methyl jasmonate on the average number and area of potato leaves (Solanum tuberosum L. var. Granola) in the $7^{\text {th }}$ week

\begin{tabular}{cccc}
\hline MeJA Concentrate $(\mathbf{p p m})$ & Height $(\mathbf{c m})$ & Number of Leaf & Leaf Area $\left(\mathbf{c m}^{2}\right)$ \\
\hline 0 (control) & $31.81^{\mathrm{a}}$ & $11^{\mathrm{a}}$ & $33.34^{\mathrm{a}}$ \\
\hline 12.5 & $32.34^{\mathrm{a}}$ & $10^{\mathrm{a}}$ & $36.15^{\mathrm{a}}$ \\
\hline 25 & $32.55^{\mathrm{a}}$ & $11^{\mathrm{a}}$ & $35.94^{\mathrm{a}}$ \\
\hline 50 & $31.84^{\mathrm{a}}$ & $12^{\mathrm{a}}$ & $35.9^{\mathrm{a}}$ \\
\hline 75 & $31.41^{\mathrm{a}}$ & $14^{\mathrm{a}}$ & $34.19^{\mathrm{a}}$ \\
\hline 100 & $30.91^{\mathrm{a}}$ & $14^{\mathrm{a}}$ & $33.73^{\mathrm{a}}$ \\
\hline
\end{tabular}

The numbers followed by the same letters in the column show no significant difference at the level $(\mathrm{p} \leq 0.05)(\mathrm{n}=6)$

Additions to the number of leaves and leaf area on plants show physiological activity for plant growth and development. DMRT analysis showed that the treatment of variations in the concentration of methyl jasmonate had no significant effect $(\mathrm{p} \leq 0.05)$ (Table 1). This shows that there is no difference between the leaves of potatoes produced. Fang \& Kao (2001) stated that the application of methyl jasmonate to rice plants affects leaf aging. Besides that, the presence of jasmonic acid decreased the gibberellins can also be a causative factor for dormancy in the axillary buds so that leaf shoots are stunted.
Leaves are a component and at the same time the place for photosynthesis and transpiration, that determines plant growth (Irwan, 2017). The biosynthesis of methyl jasmonate occurs in leaves and chloroplasts and peroxisomes are location organelles synthesized by these hormones. Janoudi \& Flore (2003) reported that the MeJA application could reduce stem length, canopy density, and area of leaf Malus baccata var. mandshurica. The results showed that the application of MeJA to $100 \mathrm{ppm}$ did not affect the vegetative growth of potato plants of the Granola variety.

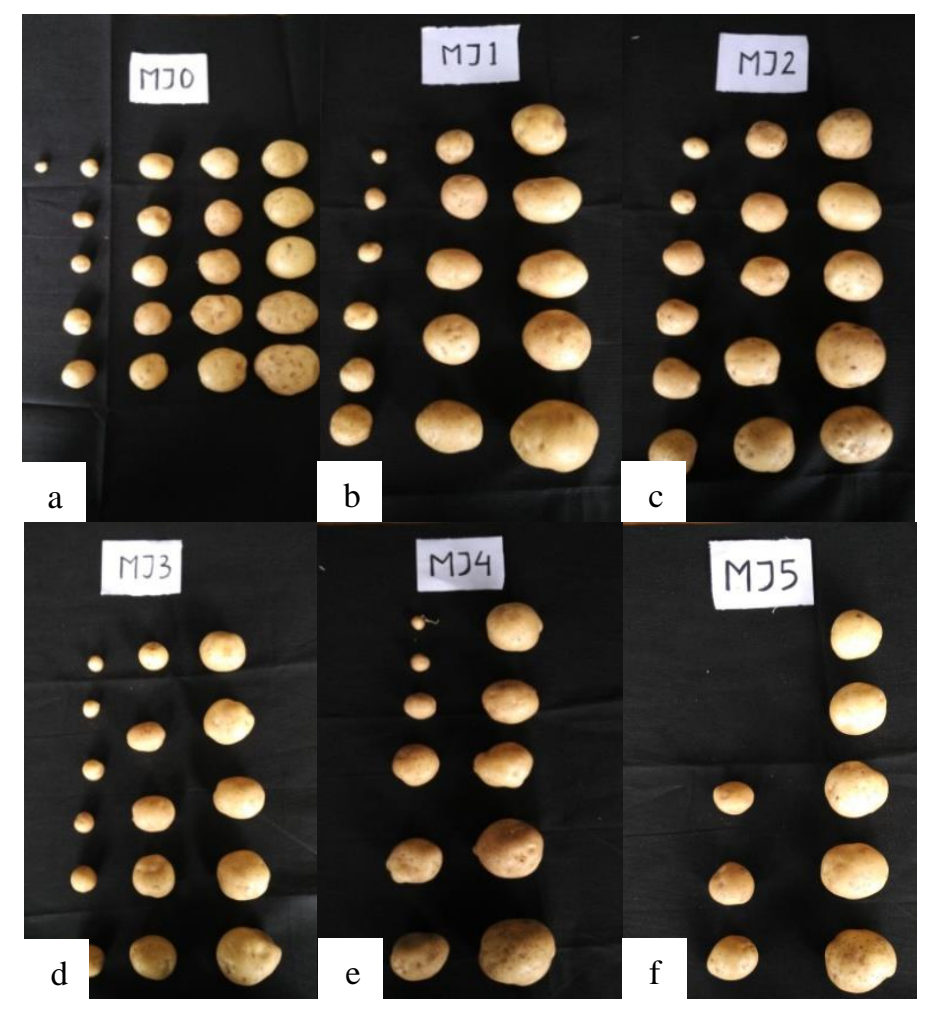

Figure 2. The effects of methyl jasmonate on potatoes tuber for each treatment: a. 0 ppm; b. 12.5 ppm methyl jasmonate; c. 25 ppm methyl jasmonate; d. 50 ppm methyl jasmonate; e. 75 ppm methyl jasmonate; f. 100 ppm methyl jasmonate 
Table 2. The numbers followed by the same letters in the column show no significant difference at the level ( $\mathrm{p} \leq 0.05)$ $(n=6)$

\begin{tabular}{cccc}
\hline MeJA Concentrate (ppm) & Mount of Tubes & Weight $(\mathbf{g})$ & Weight/Tubes (g) \\
\hline 0 (control) & $14^{\mathrm{a}}$ & $541.25^{\mathrm{b}}$ & 38.66 \\
\hline 12.5 & $10^{\mathrm{ab}}$ & $512.5^{\mathrm{b}}$ & 51.25 \\
\hline 25 & $12^{\mathrm{a}}$ & $553.75^{\mathrm{bc}}$ & 46.14 \\
\hline 50 & $8^{\mathrm{b}}$ & $537.5^{\mathrm{b}}$ & 67.18 \\
\hline 75 & $8^{\mathrm{b}}$ & $698.75^{\mathrm{c}}$ & 87.34 \\
\hline 100 & $7^{\mathrm{b}}$ & $305.75^{\mathrm{a}}$ & 43.67 \\
\hline
\end{tabular}

The numbers followed by the same letters in the column show no significant difference at the level $(p \leq 0.05)(n=4)$

In this study, plants harvested in 110 days after planting (DAP). Potato plants are ready to be harvest when the leaves turn into yellowed or dead and the tuber skin is thick or not easy to peel. The treatment of variations in the concentration of methyl jasmonate has a significant effect $(\mathrm{p} \leq 0.05)$. These show there are differences in the number of tubers and tuber weight in the treatment of methyl jasmonate. The higher the concentration of methyl jasmonate tends to reduce the number of tubers. This may be caused by the MeJA application that done only once so it is less effective in response to the number of tubers. Although the administration of methyl jasmonate reduced the number of potatoes, tubers when viewed from the average weight of plant tubers. The control treatment tended to give the highest number of tubers, but when viewed the mean tuber weight of the control treatment; the methyl jasmonate increased tuber weight.

It reported that jasmonate is structurally similar to tuberonic acid and has strong tuber induction activity (Castro et al., 2000; Debeljak et al., 2002; Gao et al., 2005). A high proportion of jasmonate can encourage protein biosynthesis in potato tubers (Acosta \& Farmer, 2010; Wasternack, 2007). The same reported by Hasibuan et al. (2015), that the differentiation of stolon into tubers in potato plants known influenced by the presence of gibberellins at the roots. The presence of gibberellins causes the elongation of the stolen (Rodríguez-Falcón et al., 2006; Muthanna et $a l, 2017)$. Therefore, compounds that exhibit anti-gibberellin activity such as paclobutrazol and cycocel are effective in increasing the number of potato tubers (Tsegaw et al., 2005; Tekalign \& Hammes, 2004; Vinod et al., 2010). This is in line with the hormone gibberellin in plants that can interact synergistically or antigenically with methyl jasmonate (Kazan et al., 2012). However, the effect of MeJA on other hormones still needs to study. Methyl jasmonate has a strong induction activity of potato bulbs. The tuberculosis of potato plants begins primarily by cell expansion. Methyl jasmonate can trigger tuber cell activities (Ulloa et al., 2002).

\section{CONCLUSION}

The treatment of methyl jasmonate does not affect the vegetative growth, height, leaf number, and leaf area of potato plants. The application of methyl jasmonate tends to reduce the number of tubers formed but increases the size and weight of tubers at a concentration of 75 ppm methyl jasmonate.

\section{REFERENCES}

Acosta IF, Farmer EE. 2010. Jasmonates. The Arabidopsis Book. vol 8: 1-13. doi: https://dx.doi.org/10.1199\%2Ftab.0129.

BPTP SUMSEL. 2014. Mengenai beberapa varietas kentang dan manfaatnya. http://sumsel.litbang.pertanian.go.id/

Camire ME, Kubow S, Donnelly DJ. 2009. Critical Reviews in Food Science and Nutrition: Potatoes and Human Health. Taylor and Francis Group, LLC. London.

Castro G, Abdala G, Agüero C, Tizio R. 2000. Interaction between jasmonic and gibberellic acids on in vitro tuberization of potato plantlets. Potato Research. vol 43(1): 83-88. doi: https://doi.org/10.1007/BF02358516.

Debeljak N, Regvar M, Dixon KW, Sivasithamparam K. 2002. Induction of tuberisation in vitro with jasmonic acid and sucrose in an Australian terrestrial orchid, Pterostylis sanguinea. Plant 
Growth Regulation. vol 36(3): 253-260. doi: https://doi.org/10.1023/A:101657031938 7.

De Putter H, Nikardi Gunadi, Uka, Romke Wustman, and Huub Schepers. 2014. Economics and agronomics of Atlantic and Granola potato cultivation in the dry season of 2013 in West Java. vegIMPACT Internal Report. Netherlands. p.7-8.

Fang WC and Kao CH. 2001. Inhibition of methyl methyl jasmonate promoted senescence in rice leaves by a metal chelator, 2,2'-bipyridine. Plant Growth Regulation. vol 33: 87-93. Doi: https://doi.org/10.1023/A:10175395135 18.

Gao X, Wang F, Yang Q, Matsuura H, Yoshihara T. 2005. Theobroxide Triggers Jasmonic Acid Production to Induce Potato Tuberization in vitro. Plant Growth Regulation. vol 47(1): 39-45. doi: https://doi.org/10.1007/s10725-0051718-8

Hasibuan S, Tantawi AR, Gusmeizal. 2015. Aktivitas Filtrat Cendawan Lasiodiploida theobromae sebagai Inhibitor Pertumbuhan Tanaman Bayam (Amaranthus spp. L.). Jurnal Agr. 2(2): 14-20.

Irwan AW, Wicaksono FY. 2017. Perbandingan pengukuran luas daun kedelai dengan metode gravimetri, regresi dan scanner. Jurnal Kultivasi. vol 16 (3): 425.

doi:

https://doi.org/10.24198/kltv.v16i3.14448

Janoudi A, Flore JA. 2003. Effects of multiple applications of methyl jasmonate on fruit ripening, leaf gas exchange and vegetative growth in fruit trees. Journal of Horticultural Science and Biotechnology. vol 78(6): 793-797.

Kazan K, Manners JM. 2012. JAZ repressors and the orchestration of phytohormone crosstalk. Trends in Plant Science. vol 17: 22-31.

Muthanna MA, Singh AK, Tiwari A, Jain VK, Padhi M. 2017. Effect of Boron and Sulphur Application on Plant Growth and
Yield Attributes of Potato (Solanum tuberosum L.). International Journal of Current Microbiology and Applied Sciences. vol 6(10): 399-404. doi: https://doi.org/10.20546/ijcmas.2017.610 .049 .

Pang JL, Wang LL, Hu JQ, Xiang TH, Liang HM. 2006. Synergistic promotion of gibberellin and cytokinin on direct regeneration of floral buds from in vitro cultures of sepal segments in sinningia speciosa hiern. In Vitro Cellular \& Developmental Biology Plant. vol 42: 450. doi: https://doi.org/10.1079/IVP2006792.

Rodríguez-Falcón M, Bou J, Prat S. 2006. Seasonal control of tuberization in potato: conserved elements with the flowering response. Annual Review of Plant Biology. vol 57: 151-180. doi: https://doi.org/10.1146/annurev.arplant.5 7.032905.105224.

Tekalign T, Hammes PS. 2004. Growth responses of potato (Solanum tuberosum) grown in a hot tropical lowland to applied paclobutrazol: 2. Tuber attributes. New Zealand Journal of Crop and Horticultural Science. vol 33(1): 43-51. doi:

https://doi.org/10.1080/01140671.2005.9 514329.

Tsegaw T, Hammes S, Robbertse J. 2005. Paclobutrazol-induced Leaf, Stem, and Root Anatomical Modifications in Potato. HortScience. vol 40(5): 1343-1346. doi: https://doi.org/10.21273/HORTSCI.40.5. 1343.

Ulloa RM, Raíces M, MacIntosh GC, Maldonado S, Téllez-Iñón MT. 2002. Jasmonic acid affects plant morphology and calcium-dependent protein kinase expression and activity in Solanum tuberosum. Physiologia Plantarum. vol 115(3): 417-427. doi: https://doi.org/10.1034/j.13993054.2002.1150312.x.

Vinod K, Vyakarnahal BS, Basavaraj N, Birbal. 2010. Effect of growth retardants and methods of application on growth and 
yield of potato. Indian Journal of Horticulture. vol 67: 308-313.

Wasternack C. 2007. Jasmonates: An Update on biosynthesis, signal transduction and action in plant stress response, growth and development. Annals of Botany. vol 100(4): 681-697. doi: https://doi.org/10.1093/aob/mcm079.
Wei-Min T, Min-Jing S, Feng-Yi Y, Ji-Lin H, Bing-Zhong, Ke-Ming C. 2003. Localized effect of mechanical wounding and exogenous jasmonic acid on the induction of secondary laticifer differentiation in relation to the distribution of jasmonic acid in Hevea brasiliensis. Acta Botanica Sinica. vol 45(11):1366-1372. 